\title{
RECENZJ A
}

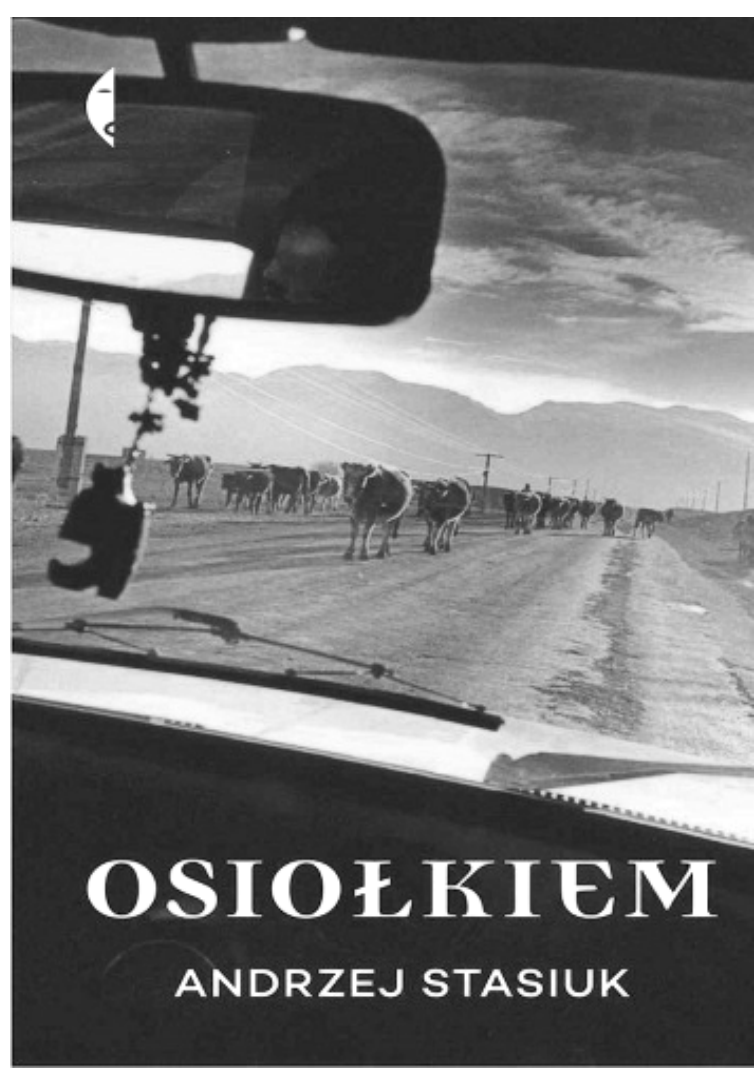

Kto $\mathrm{z}$ nas nie marzył o dalekich podróżach $\mathrm{w}$ nieznane? Książka pt. "Osiołkiem” jest opisem takiej właśnie wyprawy na wschód od granic Polski przedsięwziętej przez Andrzeja Stasiuka.

Fenomen pisarza, poety, publicysty, eseisty oraz dramaturga rozpoczął się w 1992 r. od debiutanckiej książki pt. Mury Hebronu, która została przedstawiona w formie słuchowiska na antenie radia Tok FM. Na jej podstawie powstał także spektakl muzyczny we wrocławskim Teatrze Muzycznym Capitol. Andrzej Stasiuk honorowany był za swoją twórczość wieloma nagrodami, między innymi za powieści: Jadąc do Babadag (Nagroda Nike 2005) czy Taksim (Nagroda Literacka Gdynia 2010). Sam autor tak pisze o swojej twórczości: „Mój manifest literacki? Pisać, skreślać, myśleć, patrzeć, słuchać, pisać i skreślać, skreślać, skreślać..." (www.culture.pl/pl/tworca/andrzej-stasiuk). Prozaik prowadzi z żoną Moniką Sznajderman Wydawnictwo Czarne, specjalizujące się w publikowaniu literatury z krajów środkowoeuropejskich.

\section{ANDRZEJ STASIUK}

\section{OSIOEKIEM}

\section{Wydawnictwo Czarne Wołowiec 2016} ss. 200

Co o samej książce? Jest to najnowsza powieść tego autora, wydana 26 października 2016 r. w Oficynie Literackiej Czarne w Wołowcu. Obejmuje 200 stron i ma twardą oprawę. Już sama okładka, na której znajduje się zdjęcie zrobione $\mathrm{z}$ perspektywy osoby kierującej autem sugeruje czytelnikom, że razem $\mathrm{z}$ autorem wsiądą do wysłużonego "Osiołka”, czyli ukochanego przez niego samochodu. A następnie ruszą nim do Tadżykistanu przez Ukrainę, Rosję i Kazachstan. Andrzej Stasiuk podczas pisania tej książki mówił w wywiadzie dla Onet Kultura, że w jego powieści: „Narrator jedzie do Azji starym samochodem i spotykają go różne przygody. No, ale przede wszystkim to wyznanie miłości do motoryzacji i coś w rodzaju elegii na odejście silnika spalinowego" (www.coprzeczytac. pl/osiolkiem-nowa-powiesc-andrzeja-stasiuka/).

Książka ta ujawnia jak wielką wartość mają dla bohatera, a zarazem autora samochody. Daje się odczuć duże zamiłowanie do pojazdów. Już na początku powieści autor wspomina swoje samochody, które uwa- 
ża za przyjaciół: „Pierwszym autem, do którego wsiadłem, była warszawa M-20. Ta garbata. Sąsiad miał i kiedyś mnie przewiózł. [...] Czułem się jak na latającym dywanie. I ten zapach: delikatna woń benzyny, spalin, gumy i plastiku. Chyba z pięć minut to trwało. Mgnienie i zarazem wieczność" (Osiołkiem, s. 6).

O Andrzeju Stasiuku pisał J. Andruhowycz w Piosenkach dla martwego koguta. Zadedykował mu wiersz More Than a Cult, który warto tu przytoczyć:

Stasiuk widzi wszystko.

Organ jego miłości - to pamięć wzrokowa.

Organ jego oddechu - to paczka papierosów.

Organ jego pisma - to zdezelowana maszyna do pisania. Ponieważ zdezelowana, pisze ręką.

Czyli „od ręki”, od siebie, ode mnie, od ciebie. Czyli jest jednym z nas, choć, być może, najlepszym.

To pismo jest autentyczne, to nazywa się charakter.

Po czymś takim poznaje się pisarza czy seryjnego mordercę.

A więc nigdy nie przyłapiecie go na szachrajstwie.

(Andruhowycz 2005)

Wiersz ten dobrze oddaje klimat powieści Osiotkiem. Stasiuk w swoim dziele, oprócz opisu samej podróży w głąb wschodniej Europy, pokazuje jak dużym sentymentem darzy przeszłość. Snuje refleksje nad przemijaniem, nad zmianami, jakie zaszły w Polsce, ale też uzmysławia czytelnikom, jak sami Polacy postrzegają niektóre kraje, m.in. Rosję. Autor, jak w większości swoich książek, wyraża tęsknotę za przeszłością. Na stronie 6 pisze tak: „Pomyślałem, że czasy się zmieniają i nawet kowale mają blachy i pręty poskładane według asortymentów, wszędzie pozamiatane, a pod płotem tak zwane iglaki poprzycinane w jakąś geometrię. Bo kiedyś do warstatu - tak, do «warstatu» - to się wchodziło jak do jakiejś jaskini, do groty tajemniczej". Lektura tej książki sugeruje, że autor chciałby na starość powrócić do wszystkich tych miejsc, które niegdyś odwiedził, rozłożyć mapę, wziąć lupę i przypominać sobie dawne dzieje.
Naszym zdaniem książka napisana jest lekkim językiem, miejscami z niezbyt parlamentarnymi słowami, ale stosowanymi $z$ dużym wyczuciem. Z wielką swobodą w tekst włączana jest historia, która wciąga czytelnika już od pierwszych stron. Wplatanie licznych wątków z wydarzeń obyczajowych dodaje uroku i ekspresji wielu epizodom. Osiołkiem łączy w sobie reporterski styl relacjonowania podróży $\mathrm{z}$ poetycką wizją świata. Refleksje autora cechują bezpośredniość i szczerość. W powieści przytaczane są liczne anegdoty historyczne, a także opisywane różne intrygi polityczne.

Kończąc nasze rozważania chcemy podkreślić, że recenzowana książka jest znakomitą opowieścią o podróży po Azji bez konkretnego celu, przemierzona wysłużonym samochodem. Dla autora nie jest ważne gdzie jedzie, tylko to co widzi. Wyrusza w droge przede wszystkim po to, aby poznać własne myśli i emocje, a także aby sobie powyobrażać i pomarzyć. $\mathrm{Z}$ całą pewnością książka ta jest warta polecenia nie tylko studentom, ale też innym osobom młodym i starszym, niezależnie czy interesują się motoryzacją i podróżami.

\section{BIBLIOGRAFIA}

Andruhowycz J., 2005, Piosenki dla martwego koguta, Biuro Literackie, Wrocław.

www.coprzeczytac.pl/osiolkiem-nowa-powiesc-andrzeja-stasiu $\mathrm{ka} /$

www.culture.pl/pl/tworca/andrzej-stasiuk.
Aleksandra Lewandowska Katarzyna Okręglicka 